\title{
First record of the expansive harvestmen Leiobunum sp. A (Arachnida: Opiliones) in Poland
}

\author{
Robert ROZWAŁKA ${ }^{1}$, Przemysław ŻURAWLEW ${ }^{2}$ and Tomasz RUTKOWSKI ${ }^{3}$ \\ ${ }^{1}$ Department of Zoology, Maria Curie-Skłodowska University, Akademicka 19, 20-033 Lublin, Poland; \\ e-mail: arachnologia@wp.pl (corresponding author) \\ ${ }^{2}$ Żbiki 45, 63-304 Czermin, Poland; e-mail: grusleon@gmail.com \\ ${ }^{3}$ Natural History Collections, Faculty of Biology, Adam Mickiewicz University in Poznań, Umultowska 89, \\ 61-614 Poznań, Poland; e-mail: pardosa@gazeta.pl
}

\begin{abstract}
The invasive harvestmen Leiobunum sp. A (Arachnida: Opiliones) spread rapidly across Europe. Since the first report from the Netherlands at the beginning of the 21st century its known range covers most of the western and central European countries, reaching Berlin in the East. In this note we report for the first time two new sites from Poland which move its range 230 and $300 \mathrm{~km}$ eastward, respectively. It was found in Chocz near Pleszew and Dąbrówka near Poznań (Wielkopolska Lowland). Chocz is now easternmost site of this species in Europe. Morphological measurements and drawings are given. Female genitalia are described for the first time.
\end{abstract}

Key words: Leiobunum sp. A, distribution, morphological data, invasive species, Poland

\section{INTRODUCTION}

The occurrence of previously unknown in Europe harvestmen from the genus Leiobunum C.L. Koch, 1839 was discovered for the first time in autumn of 2004 in the Netherlands (Wijnhoven 2005). In the paper published in 2007, a number of further posts of this taxon in the Netherlands, Germany, Switzerland and Austria was reported (Wijnhoven et al. 2007). The authors included the morphological description of that taxon, but did not give the formal name of the species, specifying it as Leiobunum sp. A (Wijnhoven et al. 2007). Morphological characteristics of this harvestmen indicated that it comes from the southern areas of North America. However, it could not be clearly identified due to large number of taxa known from this region of the world, not always accurately described (Wijnhoven et al. 2007). Since then, fast expansion of this species in Western Europe has been recorded. Currently the range of Leiobunum sp. A sensu Wijnhoven et al. (2007), includes north-eastern France (Noordijk et al. 2010), Luxembourg (Muster \& Mayer 2014, Muster et al. 2014), Belgium (Vanhercke 2010), The United Kingdom (Pendleton \& Pendleton 2015), the Netherlands (Wijnhoven et al. 2007, Wijnhoven 2009, 2011a, b), Germany (Arachnologische Gesellschaft 2017), Denmark (Enghoff et al. 2014) and the northern regions of Switzerland and Austria (Wijnhoven et al. 2007, Arachnologische Gesellschaft 2017, Komposch et al. 2016) (Fig. 1). In 2014, the first posts of this invasive species have also been found in Poland.

\section{MATERIAL AND METHODS}

Dąbrówka near Poznań [UTM: XU 10], Lipowa Str., on the buildings wall, 52²2'58"N 16²4'44"E, 24 Oct 2014, 10, leg. \& det. T. Rutkowski;

Vicinity of Chocz, district Pleszew [UTM: XT 96], under bridge of a small right tributary

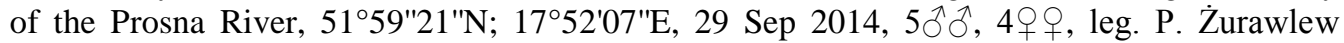
(PŻ.), det. R. Rozwałka (RR.); 15 Oct 2014, $8 \hat{\jmath} \widehat{\jmath}$, leg. PŻ., det. RR.; 21 Oct 2014, 1 , phot. 
by E. Markiewicz, det. RR.; 3 Nov 2014, 2 specimens, obs. \& det. PŻ.; 28 May 2015, 1 juv.,

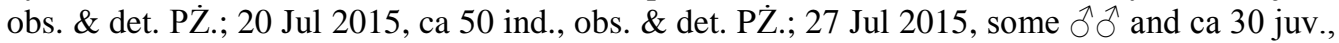
obs. \& det. PŻ.; 19 Aug 2015, ca 80 ind., obs. \& det. PŻ.; 20 Sep 2015, 39 ind., obs. \& det. PŻ.; 29 Sep 2015, 28 ind., obs. \& det. PŻ.; 15 Sep 2016, 24 ind. (obs. \& det. PŻ.), 10 Oct 2016,

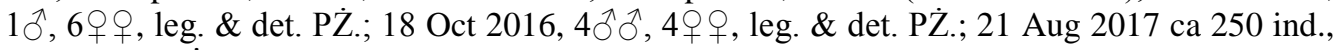
obs. \& det. Ṗ்.

In order to visualize of the receptaculum seminis, ovipositors were clarified by $10 \%$ potassium hydroxide (KOH) for 48 hours.

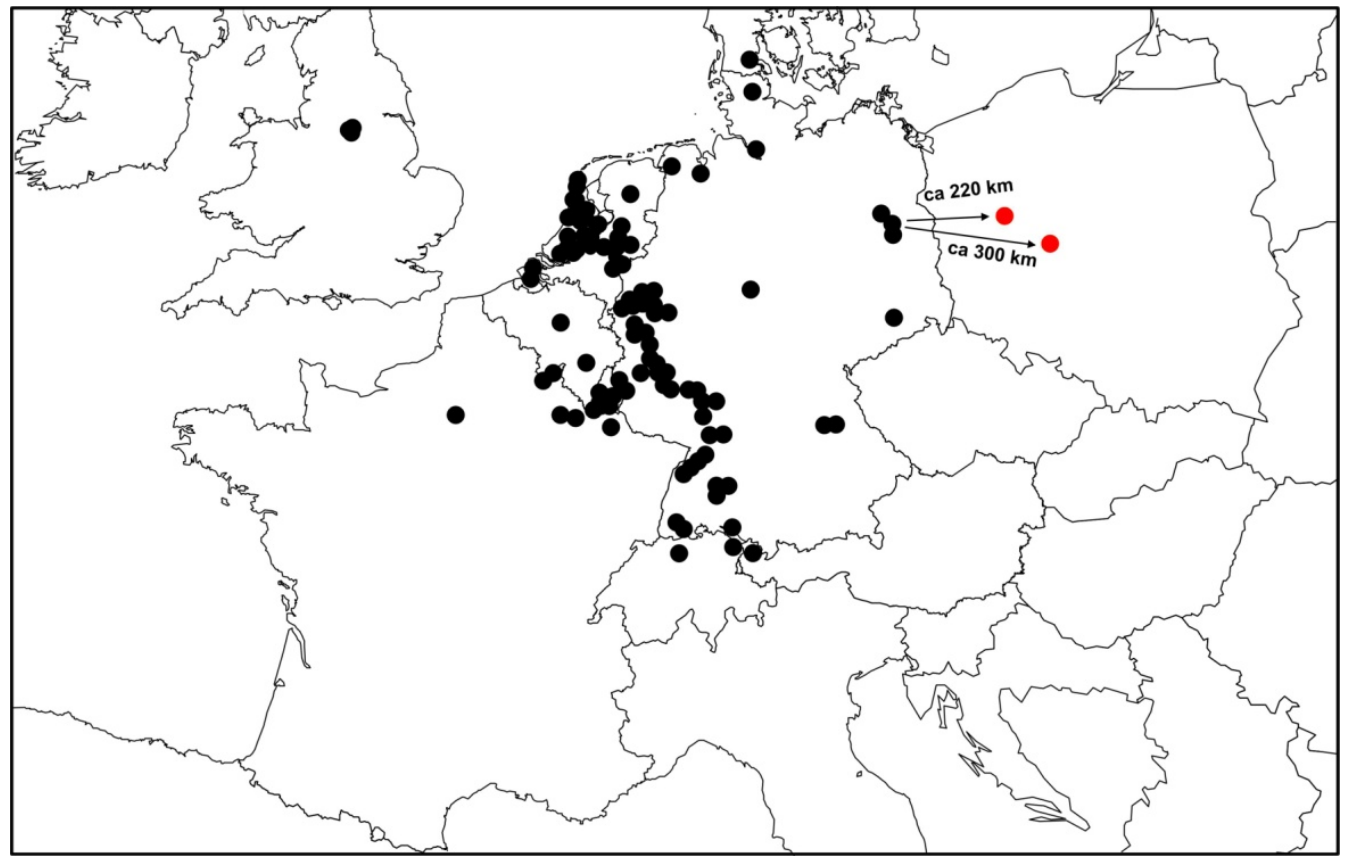

Fig. 1. Distribution of Leiobunum sp. A in Europe: black circles - published data, red circles - new data (Poland).

\section{RESULTS}

\section{Morphological characteristics}

General description. The body of a male ( $\mathrm{n}=10)$ oval, flattened, length $4.2-4.7 \mathrm{~mm}$ [4.4 mm] and width $2.3-2.7 \mathrm{~mm}$ [2.5 mm], with scutum parvum and very fine microsculpture in the abdominal part. The body of the female $(n=10)$ oval-ovoid, quite raised in abdominal part, length 5.6-6.8 $\mathrm{mm}$ [6.4 mm] and width about 4.0-4.5 $\mathrm{mm}$ [4.3]. From the base of chelicerae to the ocular tubercle extends extensive brownish-black spot, covering also ocular tubercle and connecting with a dark dorsal abdominal pattern. Ocular tubercle convex, slightly tilted to the rear, away from the front edge of the prosoma about 1.6-2.0 of its length. Ocular rings brownish-black, unarmed, only with a few minor spines. Between the eyes appear brighter (pale yellowish) longitudinal line (Figs 2a-b). On both sides of the ocular tubercle bright (whitish-yellow) stains strongly contrasting with the coloration of the rest of the body (Figs 2a-b). The basal colors of the dorsal part of the abdomen brown to brownish-black with a darker stripe in the middle, the sides a bit brighter. A female's abdomen with the dark brownish triple belt and bright, contrast, transversal band (Fig. 2b). Distinct pairs of bright (whitish, yellowish) spots on scutum parvum (Figs 2a-b). Living or freshly killed specimens have 


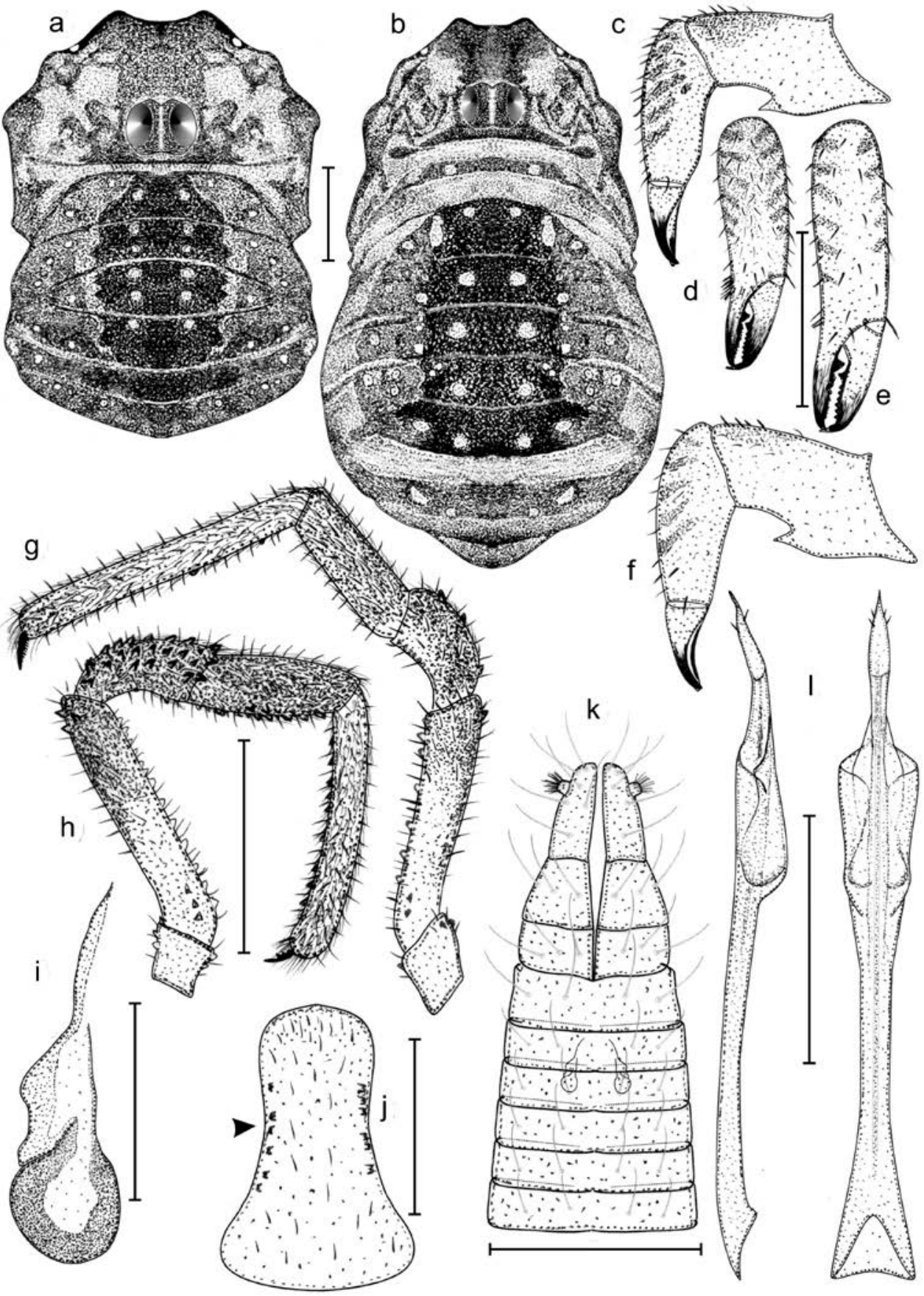

Fig. 2a-l. Leiobunum sp. A: a - body of male, dorsal view, b - body of female, dorsal view, c - chelicerae of male, lateral view, $\mathrm{d}$ - chelicerae of male, frontal view, e - chelicerae of female, frontal view, $\mathrm{f}$ - chelicerae of female, lateral view, g - pedipalp of female, medial view, h - pedipalp of male, medial view, i - receptaculum seminis, $\mathrm{j}$ - genital operculum, $\mathrm{k}$ - ovipositor with receptaculum seminis location, $\mathrm{l}$ - penis from the side (left) and dorsal (right) view. Scale bar: a-h, j, k = $1.0 \mathrm{~mm}$; $\mathrm{k}=0.5 \mathrm{~mm}, \mathrm{i}=0.05 \mathrm{~mm}$. Drawings by R. Rozwałka. 
a distinct greenish or greenish-blue, metallic gloss quickly vanishing when put in preserving alcohol. Chelicerae small, yellowish with brown striping and black pincers edges (Figs 2c-f). The male pedipalps length 3.5-4.0 mm (femur 1.0-1.4 mm), female 4.0-5.0 mm (femur 1.1$1.5 \mathrm{~mm}$ ). Femur of pedipalps ventral with distinct denticles, more numerous in males. Tibia ventral in male with thick dark grains, in female unarmed (Figs $2 g-h$ ). On the medial surface of femur, near the base, a row of 1-3 tubercles (Figs $2 g-h$ ). Patella in males with scaly denticles almost over the entire surface, in females' denticles sparse. Tarsus almost straight with a single, irregular row of dark large denticles in male (Fig. 2h). Apical parts of femur, patella and basal part of tibia gray to grayish-black, tarsus yellowish. Femur of pedipalps covered with spines, and the remaining segments spines and hairs. Genital operculum and abdominal sternites yellowish to dirty-yellowish, slightly darker than coxa. The entire abdominal area of the body and coxa almost naked, with only a few minor bright spines. Genital operculum with irregular denticulation on the edges (Fig. 2j).

Leg coxae I-IV yellowish, with a very distinct, full rows of small crown shaped denticles on pro-and retromarginal coxal edges, (only in female on the coxa III promarginal row reduced or interrupted). The membrane in coxa-trochanter joints bright white, strongly contrasting with brown trochanters. Trochanters and other segments of legs brown to brownish-black, only apical endings of femur and tibia a little brighter. In juvenile individual's ends of femur and tibia are contrast white. Legs very long (Tab. 1). Femur, patella and basal parts of tibia covered with scales forming not very regular longitudinal rows. The rest of the tibia, metatarsus and tarsus with hairs and small spines only. On tibia of all pairs of legs numerous, but poorly visible pseudoarticulations (6-12). The length of femur and the legs are presented in Table 1.

Table 1. The length of the legs and leg femurs of Leiobunum sp. A (mm) a series of $10 \widehat{\jmath}$ and 10 우, average dimensions in square brackets

\begin{tabular}{|c|c|c|c|c|c|}
\hline & Legs & $\mathrm{L}-\mathrm{I}$ & L-II & L-III & L-IV \\
\hline \multirow{2}{*}{$\hat{\sigma}$} & $\Sigma$ & $44-50[46]$ & 75-85 [79] & $42-55$ [48] & 58-67 [63] \\
\hline & $\mathrm{Fe}$ & $10.6-11.5$ [10.8] & $14.6-17.2$ [16.7] & $10.1-12.2$ [11.0] & $13.7-15.1$ [14.3] \\
\hline \multirow{2}{*}{ q } & $\Sigma$ & $42-48[44]$ & 71-77 [74] & $40-49[45]$ & 51-62 [57] \\
\hline & $\mathrm{Fe}$ & $10.1-10.9$ [10.5] & $14.5-16.9$ [16.1] & $9.3-12.0$ [10.2] & $10.6-14.2$ [12.5] \\
\hline
\end{tabular}

Genital morphology. Penis slender, weakly sclerotized, whitish, around 2.7-2.9 mm in length. Pockets narrow, weakly separated, glans strongly elongated (Fig. 2l). Ovipositor whitish, consisting of about 25-27 segments, of which the first 15-17 with prominent 2 pairs of bristles (2 pairs dorsally +2 pairs ventrally) (Fig. 2k). Length of ovipositor 3.3-3.5 mm and width $0.4-0.5 \mathrm{~mm}$. Receptaculum seminis bilobated, located in 2-3 full segment. Front receptaculum lob slit shaped, second bladdery, both with thick walls, but front one weaker sclerotized (Fig. 2i).

\section{Ecological data}

Habitat and Phenology. Leiobunum sp. A lives synanthropically, on building walls, stone walls, fences, sometimes also on trunks of trees growing nearby. Sometimes creates aggregations consisting of hundreds or even thousands of individuals (Wijnhoven et al. 2007, Wijnhoven 2008, 2009). Specimens in Poland reach their maturity in the second half of the year (August) and survive to frosts (November).

\section{DISCUSSION}

Since the first information (Wijnhoven 2005, Wijnhoven et al. 2007) rapid expansion of Leiobunum sp. A in Europe is observed. Distinctive appearance of the species and large leg span (even $18 \mathrm{~cm}$ ) helps in locating new sites of the harvestmen (Wijnhoven et al. 2007). In 
addition, this taxon has a tendency to create large, easily noticeable aggregations, which often count to several hundred or even several thousand tightly gathered individuals (Wijnhoven et al. 2007, Wijnhoven 2008). In Poland up to 250 individuals were observed but never in distinct aggregations (Fig. 3). Perhaps this is due to very limited area occupied by a population found in Poland, or the lack of appropriate environmental conditions.

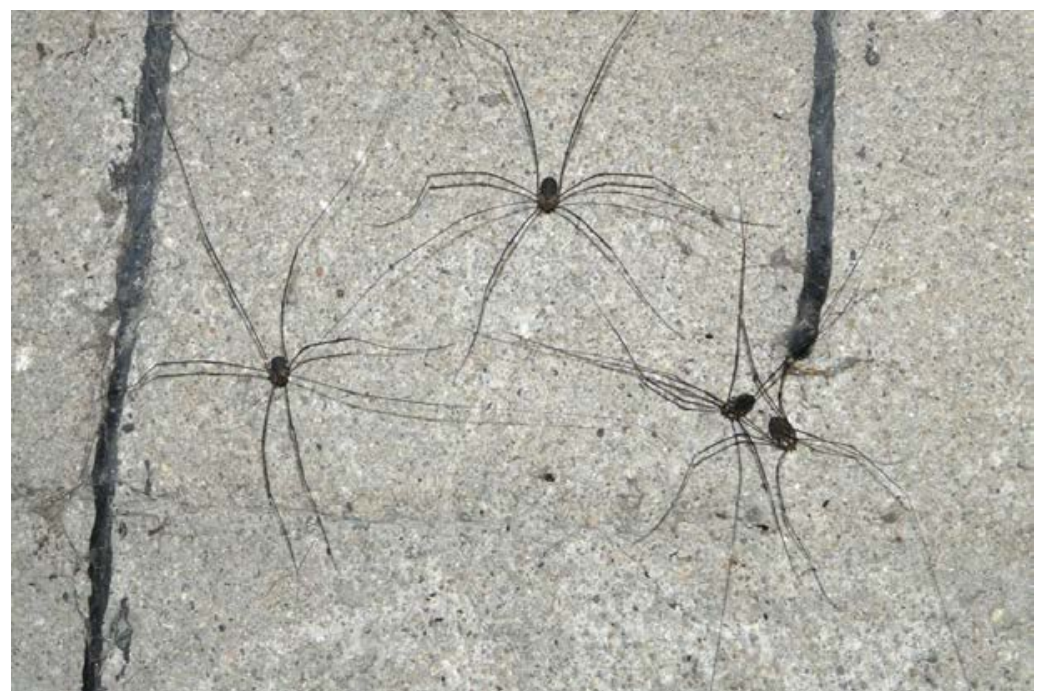

Fig. 3. A group of individuals of Leiobunum sp. A on a concrete wall in Chocz. Photo by P. Żurawlew.

A large concentration of posts of Leiobunum sp. A in the Benelux countries and in Western Germany coincides with the relatively compact range of this expansive taxon in Europe (Fig. 1). The localities in the north-east of France (Noordijk et al. 2011, Tillier 2015), Denmark (Enghoff et al. 2014), eastern parts of Germany (Friman \& Neumann 2011, Arachnologische Gesellschaft 2017) and presented here from Poland are scattered and probably represent the vanguard of the expansion. It should be expected that the process of spreading of this species in Europe will continue to proceed at a rapid pace. Indirect evidence provide cases of rapid expansion in Europe of other harvestmen species, e.g. Leiobunum limbatum (comp. Rozwałka \& Staręga 2012, Rozwałka 2015), Dicranopalpus ramosus (Rozwałka \& Rutkowski 2016), Odiellus spinosus (Rozwałka et al. 2013, 2014) that occurred in the past 20-30 years. According to data published by Wijnhoven (2011a, b) Leiobunum sp. A lays eggs in crevices and cracks in the walls. Hence presumably it can spread in Europe via transports of debris, decorative or facade stones. However, important role in spreading can probably play transportation of specimens themselves e.g. together with loads or in wagons (containers).

In Poland Leiobunum sp. A has been found on two sites (see material), but only in the area of Chocz, a constant population of this species has been observed. Leiobunum sp. A occurs there under a small bridge ( $9 \mathrm{~m}$ long and $9 \mathrm{~m}$ wide) above watercourse of a small river. The position is located among fields far away from buildings and heavily frequented routes. The nearest positions of Leiobunum sp. A from Berlin and surrounding areas (Friman \& Neumann 2011, Arachnologische Gesellschaft 2017) are 230 to $300 \mathrm{~km}$ away from Polish sites. Despite a number of research in the potential locations conducted by the authors in the years 2014-2016, no further posts of Leiobunum sp. A have been discovered. At the same time, observation of the large population in the region of Chocz indicates that this species can overwinter in climate of Western Poland. So far it seems, that discovered population is stabilised, and not ephemeral. 


\section{REFERENCES}

Arachnologische Gesellschaft 2017. Atlas of the European Arachnids. Version 1.19.2. Available at: http://atlas.arages.de (10 May 2017).

Enghoff H., Pedersen J. \& Toft S. 2014. Danske mejere - en fauna i vækst. Entomologiske Meddelelser 82: 1-12.

FRIMAN L. \& NEUMANN J. 2011. Warten auf eine Invasion von Leiobunum sp. A (Opiliones, Sclerosomatidae); Erstnachweis aus Berlin. Märkischen Entomologischen Nachrichten 13: 233-236.

Komposch Ch., Preiml S. \& BrAndNer J. 2016. Der Namenlose Rückenkanker (Leiobunum sp., Opiliones) in Österreich - Dokumentation der Ausbreitung eines neuen invasiven Weberknechts. Joannea Zoologie 15: 187-204.

Muster CH. \& MAYER M. 2014. Verbreitungsatlas der Weberknechte des Grossherzogtums Luxemburg. Ferrantia, 70 : Musée national d'histoire naturelle, Luxembourg, 112 pp.

Muster C., MeYer M. \& SATTLER T. 2014. Spatial Arrangement Overrules Environmental Factors to Structure Native and Non-Native Assemblages of Synanthropic Harvestmen. Plos ONE 9(3): e90474. DOI:10.1371/journal.pone.0090474

NoORDIJK J., WeITTEN L. \& KRUITHOF A. 2010. Une nouvelle espèce de Leiobunum (Opiliones: Sclerosomatidae) pour la faune de France, Le bulletin d'Arthropoda 44: 12-19.

Pendleton T. \& Pendleton D. 2015. Leiobunum sp. at Worksop in 2009, rediscovery in 2012 and recent records. Available at http://www.eakringbirds.com/eakringbirds3/arachnidsleiobunumsp.htm (1 Mar 2018).

RozWAŁKA R. 2015. Rozmieszczenie synantropijnych i ekspansywnych gatunków kosarzy (Arachnida: Opiliones) w polskich Karpatach. Roczniki Bieszczadzkie 23: 211-224.

RoZWAŁKA R. \& RUTKOWSKI T. 2016. First record of expansive harvestmen Dicranopalpus ramosus (SIMON, 1909) (Arachnida: Opiliones) in Poland. Fragmenta Faunistica 59: 65-71. DOI: 10.3161/00159301FF2016.59.1.063

RozWAŁKA R., RUTKOWSKI T. \& ORZECHOWSKI R. 2014. Nowe stanowiska ekspansywnego kosarza - Odiellus spinosus (Bosc, 1792) w Polsce. Przegląd Przyrodniczy 25: 54-58.

RozWAŁKA R., RUtKowSKi T. \& SiENKIEWICZ P. 2013. New data on the occurrence of two invasive harvestmen species - Odiellus spinosus (BosC) and Lacinius dentiger (C. L. KOCH) in Poland. Fragmenta Faunistica 56: 4754. DOI: 10.3161/00159301FF2013.56.1.047

ROZWAŁKA R. \& STARĘGA W. 2012. Distribution of Leiobunum limbatum L. KocH, 1861 (Opiliones: Sclerosomatidae) in Poland. Fragmenta Faunistica 55: 177-183. DOI: 10.3161/00159301FF2012.55.2.177

TILLIER P. 2015. Leiobunum sp. A [première donnée pour l'Ile-de-France]. Bulletin d'information IASEF 23: 1-2.

VANHERCKE L. 2010. Hooiwagens in België - een overzicht. Nieuwsbrief van de Belgiche Arachnologische Vereniging 25: $138-157$.

WiJNHOVEN H. 2005. Checkliste der niederländischen Weberknechte (Arachnida: Opilionida). Spined 20: 4-12.

WiJnhoven H. 2008. Hooiwagen in een hooiberg, pp. 40-42. In: KleUKERs R., Berg M. \& StRIEN W. VAN (eds), Passie voor kleine beestjes - 33,3 jaar Stichting Eis-Nederland 2008. EIS Nederland, Leiden, 90 pp.

Wijnhoven H. 2009. De Nederlandse hooiwagens (Opiliones). Entomologische Tabellen 3. Nederlandse Entomologische Vereniging, Museum Naturalis en Stichting European Invertebrate Survey - Nederland, Amsterdam, 118 pp.

WiJNHOVEN H. 2011a. De invasieve hooiwagen Leiobunum sp. A in Nederland (Arachnida: Opiliones). Entomologische Berichten 71: 123-129.

WiJNHOVEN H. 2011b. Notes on the biology of the unidentified invasive harvestman Leiobunum sp. (Arachnida: Opiliones). Arachnologische Mitteilungen 41: 17-30.

WiJnhOVEN H., SCHÖNHOFER A. \& MARTENS J. 2007. An unidentified harvestman Leiobunum sp. alarmingly invading Europe (Arachnida: Opiliones). Arachnologische Mitteilungen 34: 27-38

\section{STRESZCZENIE}

\section{[Pierwsze stwierdzenie ekspansywnego kosarza - Leiobunum sp. A (Arachnida: Opiliones) w Polsce]}

W roku 2004 na terenie Holandii pojawił się pochodzący prawdopodobnie z południowych rejonów Ameryki Północnej, introdukowany gatunek z rodzaju Leiobunum - Leiobunum sp. A. Ten nowy przybysz w europejskiej opilionofaunie charakteryzuje się bardzo długimi odnóżami, których rozpiętość sięga $18 \mathrm{~cm}$. Często tworzy duże agregacje liczące ponad 1000 osobników w załomach murów i ścian. W ciągu kilku lat od pierwszej obserwacji, Leiobunum sp. A rozprzestrzenił się w kilku krajach zachodniej Europy. Zwarty zasięg ekspansji tego taksonu obejmuje kraje Beneluxu i zachodnie Niemcy, ponadto odnotowano nieliczne stanowiska w Anglii, Austrii, Danii, Francji i Szwajcarii. W roku 2014 stwierdzono obecność Leiobunum sp. A na dwu stanowiskach w Polsce, przesuwając tym samym o ponad $200 \mathrm{~km}$ na wschód, granice ekspansji tego gatunku w Europie. 